\title{
Efficacy of ethanolic spore extract of Lycopodium clavatum in reducing induced hepatotoxicity and genotoxicity in mice
}

\author{
Surajit PATHAK ${ }^{1,2}$, Antara BANERJEE ${ }^{1,2}$ and Anisur Rahman KHUDA-BUKHSH ${ }^{1 *}$ \\ ${ }^{I}$ Department of Zoology, Cytogenetics and Cell Biology Laboratory, University of Kalyani, Kalyani, \\ India- 741235. \\ 2 Presently at: Department of Gastroenterology and Surgical Sciences, University of Padova, Padova, Italy. \\ "Corresponding author, E-mail: khudabukhsh_48@rediffmail.com; prof_arkb@yahoo.co.in \\ Phone: +91-33-5828750 extn. $315(\mathrm{O})+91-33-25828768(\mathrm{R})$ Fax: $+91-33-25828282$
}

\begin{abstract}
Ethanolic extract of spores of Lycopodium clavatum L., reportedly has profound effect against liver disorders, but lacks adequate experimental validation. To test this claim, healthy inbred Swiss albino mice, Mus musculus, were divided into different groups: Gr.I mice were fed normal diet (negative control); Gr.II - fed normal diet plus ethanol; Gr.III - fed two carcinogens of liver, [0.06\% p-dimethyl aminoazobenzene (initiator) and $0.05 \%$ phenobarbital (promoter)] known to induce hepatotoxicity and genotoxicity; Gr.IV- mice fed ethanol plus both the carcinogens, and Gr.V- fed carcinogens plus spore extract of Lycopodium clavatum. They were sacrificed at day 90 and 120 for histological studies of liver, assay of cytotoxicity markers and assessment of genotoxicity using endpoints such as chromosome aberrations, micronuclei, mitotic index in bone marrow cells and sperm head anomaly. Additionally, western blot for p53 protein expression and matrix metalloproteinase (MMP) activity in liver was compared among different groups of treated and control mice to evaluate its therapeutic potentials. Compared to Gr.III and IV, less number of mice developed tumors in Gr.V along with significant reduction in hepatotoxicity and genotoxicity, thereby validating its potential use against liver ailments as a herbal remedy.

(C) 2010 International Formulae Group. All rights reserved.
\end{abstract}

Keywords: p-dimethyl aminoazobenzene, phenobarbital, plant extract, amelioration.

\section{INTRODUCTION}

Chronic and combined feeding of the azo dye, p-dimethylamino azobenzene (p$\mathrm{DAB}$; known to be an initiator of hepatocarcinogenesis) and phenobarbital (promoter) is known to induce considerable hepatotoxicity and liver tumors in about 60 days. Some of these tumors subsequently become neoplastic with further chronic feeding of the carcinogens (Daoust, 1962; Palekar and Sirsat, 1962; Kitagawa and
Sugano, 1977; Kitagawa et al., 1979; Biswas and Khuda-Bukhsh, 2005; Biswas et al., 2004; Pathak and Khuda-Bukhsh, 2007). A long-term chronic treatment, say, for 90 days and 120 days, could ensure that the oncogenic process had been well under way. The sequential events of carcinogenesis and intervention, if any, by administration of some anti-cancer agents could be studied in this artificially induced cancer model of mice and therefore used earlier by us (Biswas et 
al., 2008, Pathak et al., 2009), particularly for testing efficacy of plant extract against hepato-toxicity and tumorigenesis.

The results obtained in our previous studies with the spore extract of Lycopodium clavatum L. (Lycopodiaceae) which is commonly referred to as "running club moss", and is a creeping perennial of world wide distribution, showed its positive modulatory effects against induced hepatotoxicity (Pathak et al., 2009). The crude extract of spores of this plant has been in use as a remedy mainly for liver ailments in various traditional systems of medicine and also known to exhibit anti-proliferative and anti-oxidative potentials (Rusu et al., 2005; Mandal et al., 2010). Lycopodium clavatum contains many alkaloids (Ma and Dang, 2004) of which the major one is Huperzine A.

In continuation of the previous work, the present study was intended to i) verify anti-hepatotoxic potentials of Lycopodium clavatum in mice, in respect of some other acceptable parameters not used earlier; ii) and whether, the plant extract could also bring about demonstrable reduction in genotoxicity that is induced by the carcinogens, by deploying cytogenetic endpoints like chromosome aberrations, micronuclei, mitotic index of bone marrow cells and sperm head abnormality; and finally iii) to correlate the findings obtained through this study and evaluate the possible impact and suitability of administration of this plant extract as a supportive remedy in complementary and alternative medicinal therapy against hepatotoxicity and genotoxicity. Therefore, along with the cytogenetic assessment of genotoxicity, some biochemical toxicity parameters were also used, such as assays of the activities of alanine and aspartate amino transferases (ALT, AST), catalase (CAT), and lipid peroxidation (LPO) and reduced glutathione content (GSH) in liver. Concurrently, the anti-tumorigenic potentials of the extract were assessed by recording direct manifestation of liver nodules as well as by analyzing the expression of matrix metalloproteinase and detection of p53 protein expression by western blot. Further, to confirm if the improvement in the cytotoxicity and genotoxicity was also reflected in improvement of the induced structural damage in liver, histological studies through optical, scanning and transmission electron microscopies were carried out in experimental groups.

\section{MATERIALS AND METHODS Animals}

Healthy inbred strain of Swiss albino mice (Mus musculus) were used for the present study. Mice were provided with food and water ad libitum. The food was generally made up of wheat, gram and powdered milk without any further animal protein supplementation. The experimental protocols were in accordance with the guidelines laid down by the Animal Ethics Committee and the Animal Welfare Committee, University of Kalyani, West Bengal, India.

\section{Experimental protocol}

For the induction of cytotoxicity and genotoxicity the chronic dietary feeding method of $p$-dimethylamino azobenzene ( $p$ $\mathrm{DAB}$ ) and phenobarbital (PB) was adopted. A group of 35 healthy mice weighing between 25-30 gm were used for each of the fixation intervals. Each group of 35 mice were divided into five different sets consisting of 7 mice each for normal diet fed (Gr.I), normal diet + Ethanol fed (Gr.II), p$\mathrm{DAB}+\mathrm{PB}$ (Gr.III), p-DAB + PB + Ethanol (Gr.IV), and p-DAB $+\mathrm{PB}+$ spore extract of Lycopodium clavatum (Gr.V) fed series. The Gr.I mice (negative control) were allowed normal diet. The Gr.II mice were fed $0.06 \mathrm{ml}$ (60 $\mu \mathrm{l} / \mathrm{drop}$, in a pipette) of $90 \%$ ethanol along with normal diet. The Gr.III mice were fed food mixed with $0.06 \%$ p-DAB (Sigma, D-6760) and provided $0.05 \%$ aqueous solution of PB (Pathak and Khuda-Bukhsh, 2007). The carcinogen fed mice were also fed $0.06 \mathrm{ml}$ of $90 \%$ ethanol (Gr.IV) to serve as 
the positive control group. The Gr.V mice were fed p-DAB plus PB as in Gr. III, but were also fed $0.06 \mathrm{ml}$ of spore extract of Lycopodium clavatum once daily (8 a.m.) till they were sacrificed at day 90 and 120 .

Mice were injected (intra-peritonially) with $0.03 \%$ colchicine at the rate of $1 \mathrm{ml} / 100$ gm body weight $90 \mathrm{~min}$ before sacrifice. Marrow of the femur was collected and flushed in $1 \%$ sodium citrate solution at 37 ${ }^{\circ} \mathrm{C}$ and fixed in acetic acid/ethanol (1:3) for cytogenetical study.

Liver tissue of sacrificed mice were quickly collected in an ice tray and differently processed for the estimation of biochemical parameters, study of metalloproteinases activity, western blot for p53 protein expression and also for histological studies.

\section{Preparation of the plant extract}

The ethanolic extract of spores of Lycopodium clavatum, was procured from HAPCO, 165, BB Ganguly Street, Kolkata 700014. During the process of preparation, dried plant spores were macerated with $90 \%$ alcohol (ethanol) and filtered. Filtrate was evaporated to a thick residue at $50{ }^{\circ} \mathrm{C}$. The yield of the extract was about $60 \%$. The extract was re-suspended in $90 \%$ alcohol (ethanol) and used for in vivo experiments with suitable dilution.

\section{Feeding procedure and dose}

Each mouse was fed $0.06 \mathrm{ml}$ of either $0.05 \%$ PB or $90 \%$ ethanol or extract once daily through gavages by dropping on tongue with the aid of a fine pipette as per requirement of a particular series.

\section{Studies of tumor incidence}

On autopsy, the tumor incidence was recorded in carcinogen fed and carcinogen plus extract fed mice.

\section{Cytogenetical study}

The standard and accepted cytogenetic protocols like assays of chromosome aberrations (CA), micronuclei (MN), mitotic index (MI) and sperm head anomaly (SHA) have been adopted in the present study.

Slides were prepared by the conventional flame drying technique as previously described (Biswas et al., 2004) followed by Giemsa staining for scoring bone marrow chromosome aberrations. A total of 300 bone marrow cells were observed.

For micronucleus preparation, a part of the suspension of bone marrow cells in $1 \%$ sodium citrate was smeared on clean grease free slides, briefly fixed in methanol and subsequently stained with May-Grunwald followed by Giemsa (Schmid, 1976). Approximately 3000 bone marrow cells, comprising both polychromatic erythrocytes (PCE) and normochromatic erythrocytes (NCE) were scored.

The mitotic index (MI) was determined from the same slide that was scanned for MN, and a total of 5000 cells were examined from each series. The nondividing and dividing cells were recorded and their ratios ascertained.

For sperm head anomaly, the technique of Wyrobek et al. (1984) was adopted. 5000 sperm were examined in each series.

\section{Biochemical parameters}

Quantitative estimation of total protein was made by the method of Lowry et al. (1951). For estimation of AST and ALT activities, the method of Bergmeyer and Brent (1974) was followed. The lipid peroxidation was estimated according to the method of Buege and Aust (1984). In case of estimation of reduced glutathione (GSH), the method of Ellman (1959) was followed and catalase activity was measured using the method of Chance and Maehly (1955).

\section{Histological studies}

Histological slides of liver for optical microscopy at days 90 and 120 were prepared based on standard methods. 
The detailed procedures of fixation and section cutting for scanning and transmission electron microscopy (SEM and TEM, respectively) have been described earlier (Pathak et al., 2007).

\section{Study of the expression level of metalloproteinase from liver tissue}

For the study of matrix metalloproteinase activity, the procedure of Billings et al. (1991) was followed.

\section{Western blot analysis for $\mathrm{p53}$ protein expression}

Detection of p53 proteins was made by the Western Blotting method (Maggi et al., 1999). p53 (Pab-240), a mouse monoclonal antibody raised against amino acids 156-214 of p53 of human origin, and the secondary antibody, goat-anti-mouse $\mathrm{IgG}_{1}$-HRP, were purchased from Santa Cruz Biotechnology, Inc.

\section{Blinding and statistical analysis of data}

During the experiment and analysis of data the "observer" was kept "blinded" if the animal belonged to "treated" or "control" group in order to remove any "bias" in experiment and thereby uniformity was maintained in observation and scoring data of both treated and control sets of mice. The levels of significance between different series of data were analyzed by Student's t-test and $\mathrm{p} \quad$ values $\quad(*=\mathrm{P}<0.05, \quad * *=\mathrm{P}<0.01$, $* * *=\mathrm{P}<0.001, \mathrm{n}=$ non significant $)$.

\section{RESULTS}

\section{Tumor incidence}

In general, all the mice fed $p$ $\mathrm{DAB}+\mathrm{PB}$ (Gr.III) and p-DAB+PB+Ethanol (Gr.IV) developed tumor nodules in liver in both 90 and 120 days fixation intervals. But the numbers of mice showing tumor nodules in $\mathrm{p}-\mathrm{DAB}+\mathrm{PB}+$ spore extract of Lycopodium clavatum (Gr.V) fed series were less than the carcinogen fed ones. At 90 days fixation interval, 3 out of 7 mice and at 120 days 2 out 7 mice developed pale reddish tumor nodules in Gr.V mice (Figures 1a-1c).

\section{Cytogenetical studies \\ Chromosome aberrations}

The total frequencies of $\mathrm{CA}$ were found to be very high in the p-DAB+ $\mathrm{PB}+$ Ethanol (Gr.IV) fed mice (Table 1). There was, however, a much less incidence of CA in the $\mathrm{p}-\mathrm{DAB}+\mathrm{PB}+$ spore extract of Lycopodium clavatum (Gr. V) fed group, indicating significant amount of suppression of CA, both at day 90 and day 120 .

\section{Micronucleated erythrocytes}

The percentages of MN were generally much lesser (Table 1) in the Gr.V mice as compared to either Gr. III or Gr.IV mice at both the fixation intervals.

\section{Mitotic index}

In Gr.V mice, the MI was much less and the extent of suppression as compared to intoxicated controls was statistically significant $(\mathrm{p}<0.05$ through $\mathrm{p}<0.001)$. MI in the carcinogen fed mice was also appreciably higher than in the normal healthy controls $(\mathrm{p}<0.001)$ (Table 1).

\section{Sperm head anomaly}

Quite a high incidence of sperm showing some form of abnormal head morphology (SHA) has been recorded in the carcinogen fed series (Table 1). In Gr.V mice, the SHA frequency was considerably reduced and the differences were statistically significant at both fixation intervals.

\section{Biochemical studies AST and ALT activities}

The AST and ALT activities in mice fed p-DAB + PB + Ethanol were appreciably enhanced in liver tissue at both the fixation intervals. However, the AST and ALT activities in the group of mice fed plant extract along with the carcinogens were appreciably decreased at both the fixation intervals $(\mathrm{p}<0.05$ to $\mathrm{p}<0.001)$ (Table 2).

\section{Lipid peroxidation}

LPO also significantly decreased in Gr.V mice as compared to carcinogen fed 
series at both the fixation intervals in liver tissue (Table 2).

\section{Reduced glutathione content}

An increased level of reduced glutathione was observed in the Gr.V mice at both the fixation intervals, as compared to $\mathrm{p}$ $\mathrm{DAB}+\mathrm{PB}$ (Gr.III) or p-DAB + $\mathrm{PB}+$ Ethanol (Gr.IV) fed series (Table 2).

\section{Catalase activity}

There was a significant increase in activities of these enzymes in liver of the Gr.V mice as compared to the reduced activities noted in the carcinogen fed mice (Table 2) at both the fixation intervals.

\section{Histological studies Optical microscopy}

Under optical microscopy, the liver sections of $\mathrm{p}-\mathrm{DAB}+\mathrm{PB}+\mathrm{Ethanol}$ fed mice at day 120 (Figure 2b) revealed more drastic tissue damage and necrosis compared to the liver sections of normal controls (Figure 2a). A few notable areas of damage caused by the carcinogens were as follows: more than one nucleus was present in some hepatocytes, excessive fibrosis in the hepatic parenchyma was noticed; and cytoplasmic boundaries of the hepatic cells were barely recognizable and also more infiltration of leukocytes among the parenchyma was evident. In p$\mathrm{DAB}+\mathrm{PB}+$ Lycopodium clavatum $(\mathrm{Gr} . \mathrm{V})$ fed series (Figure 2c) the overall effect was considerably reduced, e.g., the bi-nucleate or multinucleate cells were much fewer, and more cells had distinct boundaries.

\section{Scanning electron microscopic studies}

As compared to normal diet fed series (Figures 3a, 3b), the chronic feeding of $\mathrm{p}$ $\mathrm{DAB}+\mathrm{PB}+$ Ehanol for 90 and 120 days, respectively, induced various changes in the histological structure of liver in mice. There was indication of excessive fibrosis of the hepatocytes (Figure 3c); cells were small and more than one nucleus was present, vacuolated cells were present in some cells and no cytoplasmic boundaries were evident. Damaged hepatic cells and hepatic cell boundaries were found in case of carcinogen treated series (Figure 3d) and relatively less damage and recognizable hepatic cell boundaries were encountered in the $\mathrm{p}$ $\mathrm{DAB}+\mathrm{PB}+$ Lycopodium clavatum (Gr.V) fed series (Figures 3e, 3f). Further, the number of hepatocytes apparently increased in the carcinogen fed mice, which appeared to be relatively less in the extract plus carcinogen intoxicated group.

Transmission electron microscopic studies

In contrast to the intact nuclear membrane and mitochondria with prominent cristae observed in liver of normal control (Figures 4a, 4b), nuclear membrane in liver cells of the p-DAB + PB fed mice appeared to be broken in nature (Figure $4 \mathrm{c}$ ). There were signs of destructive changes occurring in cristae of mitochondria of the carcinogen treated mice and also showing greater number of mitochondria, which were less conspicuous in Gr.V mice. Black lipid droplets and glycogen materials were found in liver of carcinogen treated mice (Figure 4d), which represented a prominent marker of toxicity. Such lipid droplets and glycogen materials were found less in number in the $\mathrm{p}$ $\mathrm{DAB}+\mathrm{PB}+$ Lycopodium clavatum (Gr.V) fed series (Figure 4e, 4f).

Zymogram profile for metalloprotease activity

In Gr.V mice, the expression of MMPs appeared to be much lower than in the carcinogen-intoxicated series (Figures 5a, $5 b)$.

Detection of p53 protein by Western blotting

The expression of $\mathrm{p} 53$ protein in normal mice at day 90 and 120 (Figures 6a, $6 b)$ is shown in Lane-1. In both Lane-2 (p$\mathrm{DAB}+\mathrm{PB})$ and Lane-3 (p$\mathrm{DAB}+\mathrm{PB}+$ Ethanol), there was a visible increase in the expression of the $\mathrm{p} 53$ protein. In Gr.V mice the expression of p53 protein was significantly reduced at day 90 and 120 as compared to $\mathrm{p}-\mathrm{DAB}+\mathrm{PB}+$ Ethanol fed control mice. 
S. PATHAK et al. / Int. J. Biol. Chem. Sci. 4(3): 770-781, 2010

Table 1: Frequency distributions of chromosome aberrations (CA), micronuclei (MN), mitotic indices (MI) and sperm head anomaly (SHA) of different series of mice at different fixation intervals.

\begin{tabular}{|c|c|c|c|c|c|c|c|c|}
\hline \multirow[t]{2}{*}{ Series } & \multicolumn{2}{|c|}{$\mathrm{CA}(\% \mathrm{CA} \pm \mathrm{SE})$} & \multicolumn{2}{|c|}{$\mathrm{MN}(\% \mathrm{MN} \pm \mathrm{SE})$} & \multicolumn{2}{|c|}{$\mathrm{MI}(\% \mathrm{MI} \pm \mathrm{SE})$} & \multicolumn{2}{|c|}{ SHA $(\%$ SHA \pm SE $)$} \\
\hline & 90 days & 120 days & 90 days & 120 days & 90 days & 120 days & 90 days & 120 days \\
\hline Normal & $4.2 \pm 0.10$ & $4.5 \pm 0.02$ & $0.180 \pm 0.01$ & $0.195 \pm 0.01$ & $0.76 \pm 0.02$ & $0.76 \pm 0.02$ & $0.46 \pm 0.02$ & $0.46 \pm 0.02$ \\
\hline Normal+ Ethanol & $6.3 \pm 0.40$ & $6.7 \pm 0.03$ & $0.195 \pm 0.02$ & $0.210 \pm 0.02$ & $0.84 \pm 0.02$ & $0.84 \pm 0.02$ & $0.54 \pm 0.06$ & $0.54 \pm 0.06$ \\
\hline $\mathrm{p}-\mathrm{DAB}+\mathrm{PB}$ & $18.0 \pm 0.29$ & $21.5 \pm .0 .15$ & $1.105 \pm 0.02$ & $1.100 \pm 0.02$ & $5.60 \pm 0.04$ & $6.68 \pm 0.05$ & $2.70 \pm 0.04$ & $3.28 \pm 0.06$ \\
\hline $\mathrm{p}-\mathrm{DAB}+\mathrm{PB}+$ Ethanol & $20.0 \pm 0.30$ & $28.0 \pm 0.02$ & $1.080 \pm 0.01$ & $1.140 \pm 0.01$ & $7.44 \pm 0.05$ & $8.98 \pm 0.06$ & $3.40 \pm 0.03$ & $3.80 \pm 0.03$ \\
\hline $\begin{array}{c}\mathrm{p}-\mathrm{DAB}+\mathrm{PB}+\text { Lycopodium } \\
\text { clavatum }\end{array}$ & $11.5 \pm 0.23^{\text {*** }}$ & $14.0 \pm 0.02^{* * *}$ & $0.750 \pm 0.01^{* * *}$ & $0.825 \pm 0.01^{* * *}$ & $2.58 \pm 0.04^{* * *}$ & $2.24 \pm 0.02^{* * *}$ & $1.30 \pm 0.03^{* * *}$ & $1.12 \pm 0.04^{* * *}$ \\
\hline
\end{tabular}

$\mathrm{SE}=$ standard error, $*=\mathrm{P}<0.05, * *=\mathrm{P}<0.01, * * *=\mathrm{P}<0.001, \mathrm{n}=$ non significant.

Table 2: Mean activities of aspartate aminotransferase (AST) (nM/100mg protein/Min), alanine aminotransferase (ALT) (nM/100mg protein/Min), lipid peroxidation (LPO) $(\mathrm{nM} / \mathrm{MDA} / \mathrm{mg}$ wet tissue), reduced glutathione $(\mathrm{GSH})(\mathrm{nM} / \mathrm{mg}$ Wet Tissue) contents, catalase (unit of enzyme/mg protein) in different series of mice at different fixation intervals.

\begin{tabular}{|c|c|c|c|c|c|c|c|c|c|c|}
\hline \multirow{2}{*}{ Series } & \multicolumn{2}{|c|}{ AST } & \multicolumn{2}{c|}{ ALT } & \multicolumn{3}{c|}{ LPO } & \multicolumn{2}{c|}{ GSH } & \multicolumn{2}{c|}{ Catalase } \\
\cline { 2 - 10 } & $\mathbf{9 0}$ days & $\mathbf{1 2 0}$ days & $\mathbf{9 0}$ days & $\mathbf{1 2 0}$ days & $\mathbf{9 0}$ days & $\mathbf{1 2 0}$ days & $\mathbf{9 0}$ days & $\mathbf{1 2 0}$ days & $\mathbf{9 0}$ days & $\mathbf{1 2 0}$ days \\
\hline Normal & $0.011 \pm 0.001$ & $0.055 \pm 0.002$ & $0.005 \pm 0.001$ & $0.005 \pm 0.000$ & $0.040 \pm 0.000$ & $0.044 \pm 0.000$ & $0.006 \pm 0.000$ & $0.006 \pm 0.000$ & $8.80 \pm 0.02$ & $8.70 \pm 0.001$ \\
\hline Normal+ Ethanol & $0.013 \pm 0.008$ & $0.053 \pm 0.003$ & $0.006 \pm 0.001$ & $0.005 \pm 0.001$ & $0.094 \pm 0.016$ & $0.082 \pm 0.007$ & $0.006 \pm 0.000$ & $0.007 \pm 0.000$ & $8.60 \pm 0.001$ & $8.50 \pm 0.001$ \\
\hline p-DAB+PB & $0.055 \pm 0.004$ & $0.071 \pm 0.010$ & $0.014 \pm 0.003$ & $0.020 \pm 0.001$ & $0.115 \pm 0.016$ & $0.069 \pm 0.012$ & $0.005 \pm 0.000$ & $0.003 \pm 0.001$ & $4.30 \pm 0.001$ & $2.60 \pm 0.002$ \\
\hline p-DAB+PB+ Ethanol & $0.057 \pm 0.001$ & $0.109 \pm 0.013$ & $0.015 \pm 0.002$ & $0.021 \pm 0.002$ & $0.121 \pm 0.003$ & $0.148 \pm 0.008$ & $0.003 \pm 0.001$ & $0.003 \pm 0.001$ & $3.90 \pm 0.004$ & $2.10 \pm 0.001$ \\
\hline $\begin{array}{c}\text { p-DAB+PB+Lycopodium } \\
\text { clavatum }\end{array}$ & $0.041 \pm 0.004^{* * *}$ & $0.058 \pm 0.009^{*}$ & $0.003 \pm 0.000^{* * * *}$ & $0.019 \pm 0.001^{\mathrm{n}}$ & $0.089 \pm 0.020^{\mathrm{n}}$ & $0.124 \pm 0.020^{\mathrm{n}}$ & $0.008 \pm 0.030^{\mathrm{n}}$ & $0.005 \pm 0.000^{\mathrm{n}}$ & $5.20 \pm 0.003^{* * * *}$ & $5.80 \pm 0.001^{* * * * * *}$ \\
& & & & & & & & & \\
\hline
\end{tabular}



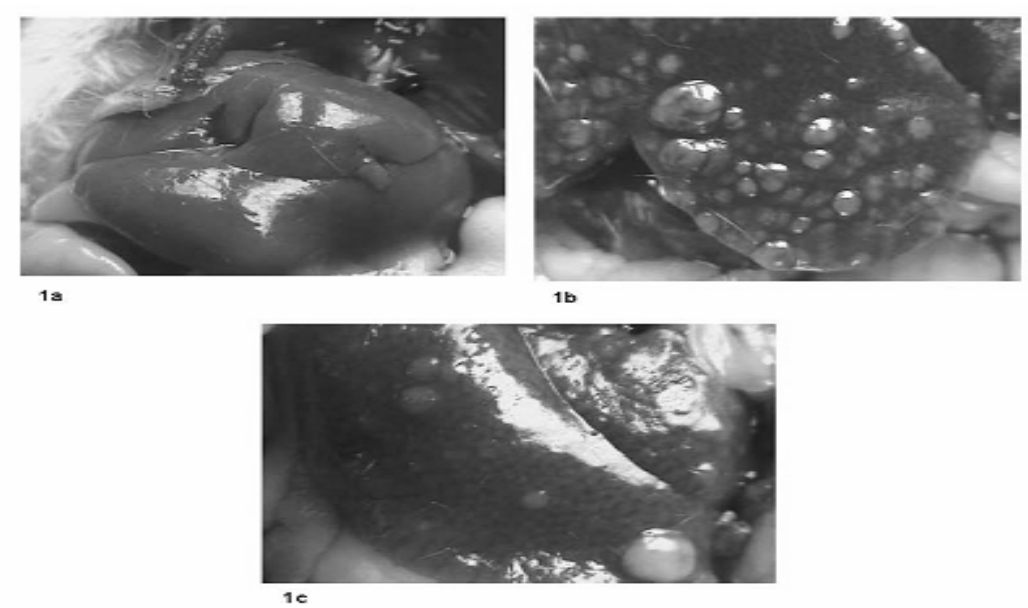

Figure 1a-1c: Representative photographs of liver of mice showing: (1a) Liver of normal diet fed mice without any nodules; (1b) liver of p-DAB+PB+Ethanol fed mice with numerous nodules and (1c) Liver of $\mathrm{p}-\mathrm{DAB}+\mathrm{PB}+$ Lycopodium clavatum fed mice, with less number of nodules.
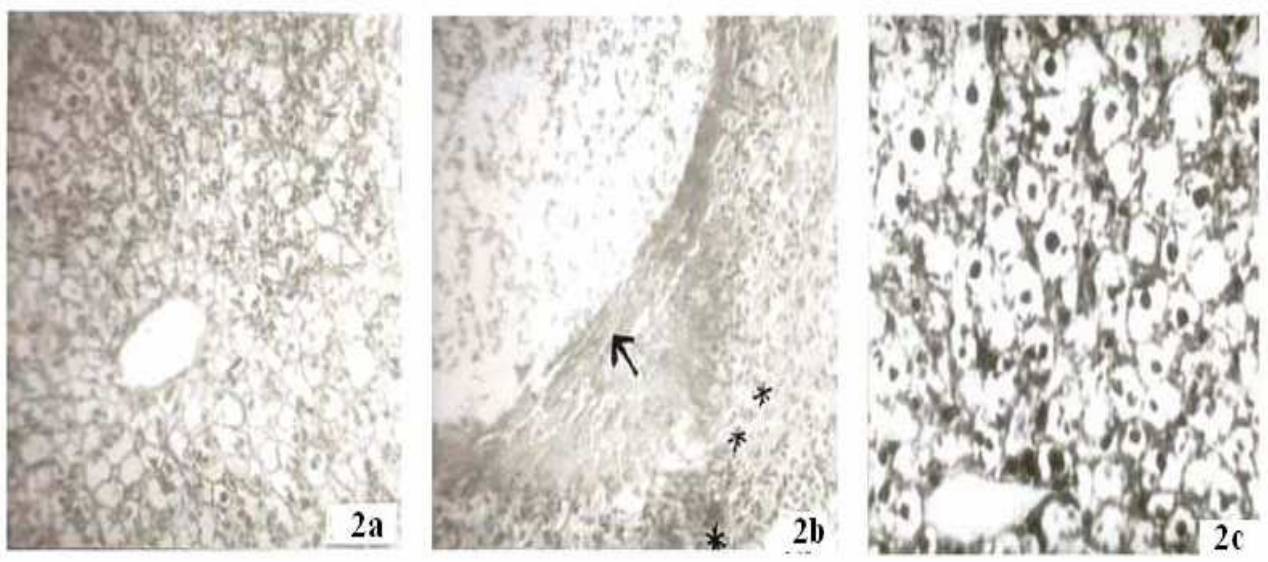

Figure 2a-2c: Histological sections of liver: In normal controls (2a), in p-DAB+PB+Ethanol fed mice (2b) and p-DAB+PB+Lycopodium clavatum fed mice (2c) showing liver tissue with necrosis/fibrosis and proliferation of cells.

\section{DISCUSSION}

Tumors were developed at both intervals of fixation in all mice fed with the carcinogens and in the carcinogens plus ethanol fed group, but only five out of fourteen had any tumor nodules observed in the $\mathrm{p}-\mathrm{DAB}+\mathrm{PB}+$ Lycopodium clavatum fed series, showing quite appreciable anti-tumor activity of this drug.
The chronic feeding of the carcinogens induced hepato-toxicity as revealed from the increased levels of ALT, AST, and LPO and decreased level of catalase activity and GSH content. The administration of the spore extract substantially brought down the levels of the former biomarkers and increased the GSH content and catalase activity in mice chronically intoxicated with the carcinogens. 

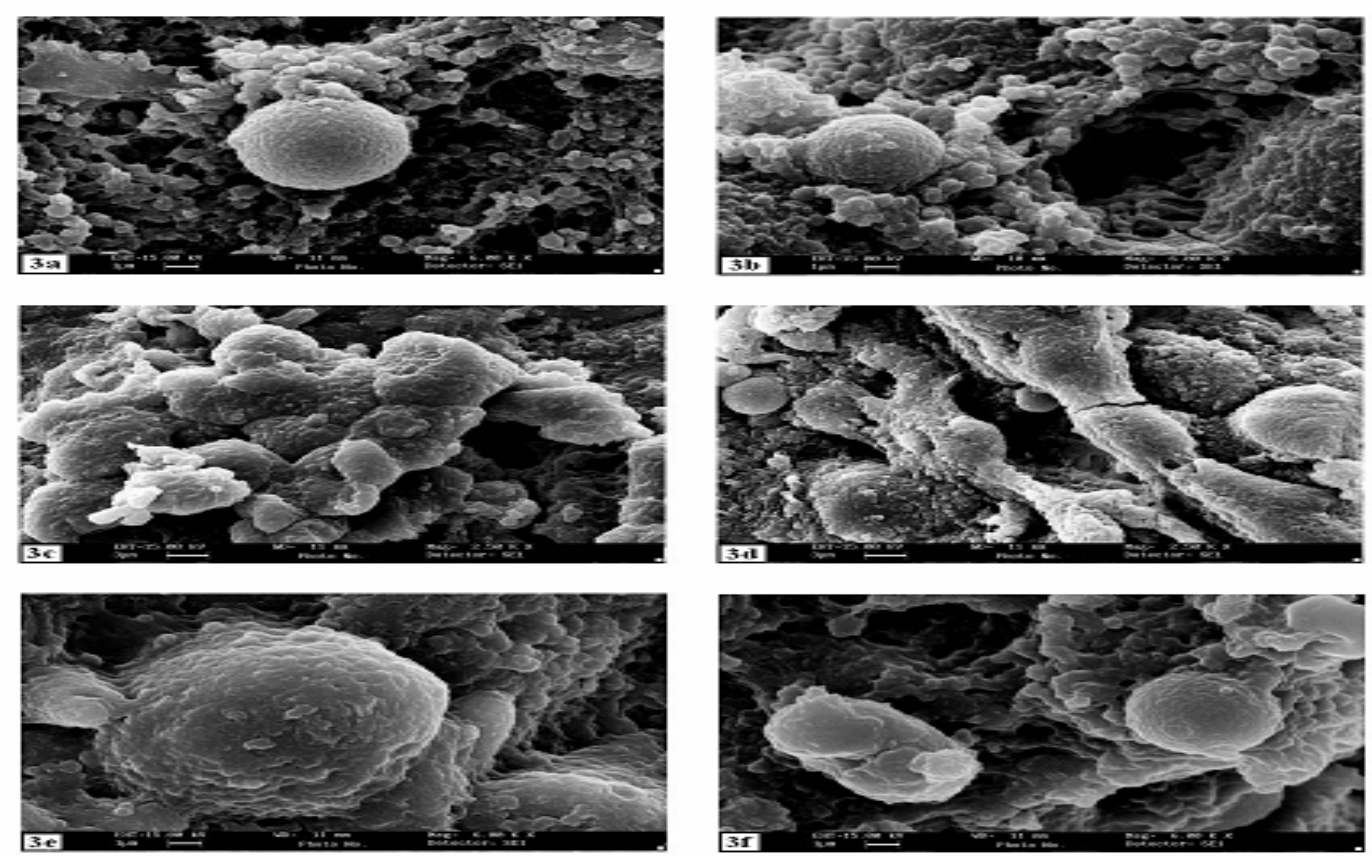

Figure 3a-3f: Representative figures of liver sections under scanning electron microscopies (SEM) showing features of liver tissue of normal diet fed mice (3a-3b), p-DAB+PB+Ethanol fed mice (3c$3 \mathrm{~d})$ and $\mathrm{p}-\mathrm{DAB}+\mathrm{PB}+$ Lycopodium clavatum fed mice (3e-3f).
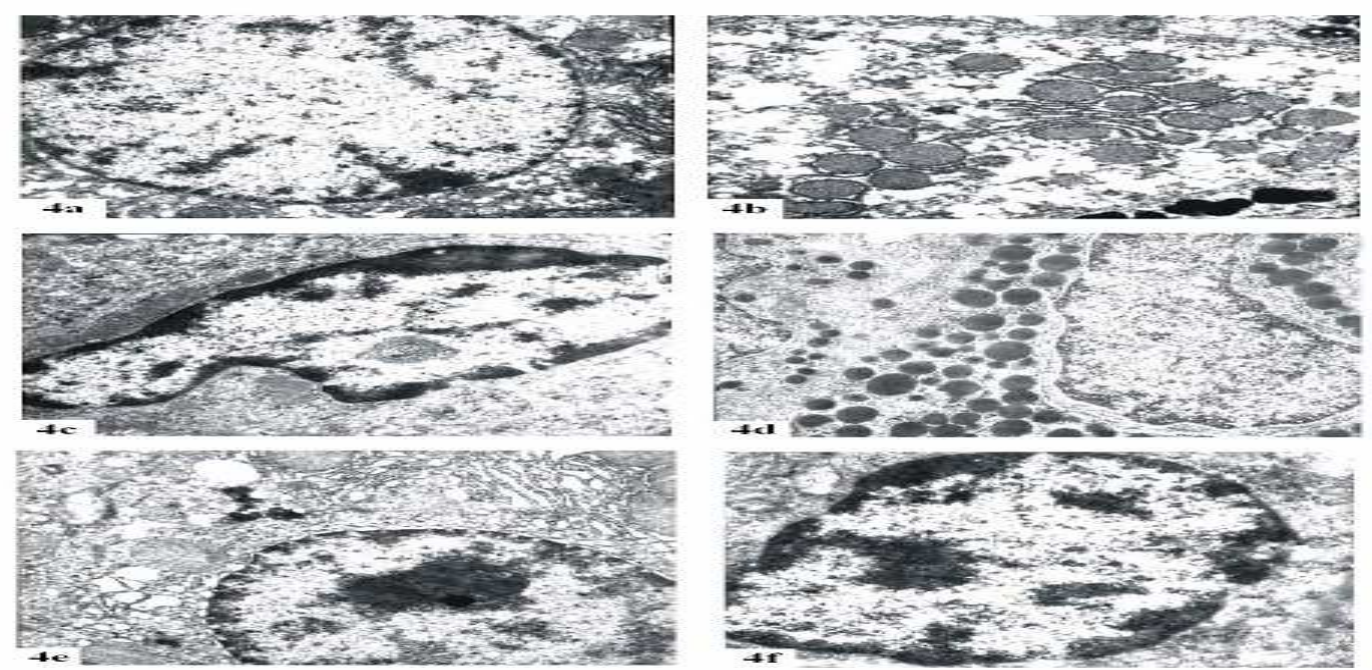

Figure 4a-4f: Representative figures of liver sections under transmission electron microscopies (TEM) showing features of liver tissue of normal diet fed mice (4a-4b), p-DAB+PB+Ethanol fed mice $(4 \mathrm{c}-4 \mathrm{~d})$ and $\mathrm{p}-\mathrm{DAB}+\mathrm{PB}+$ Lycopodium clavatum fed mice $(4 \mathrm{e}-4 \mathrm{f})$. 


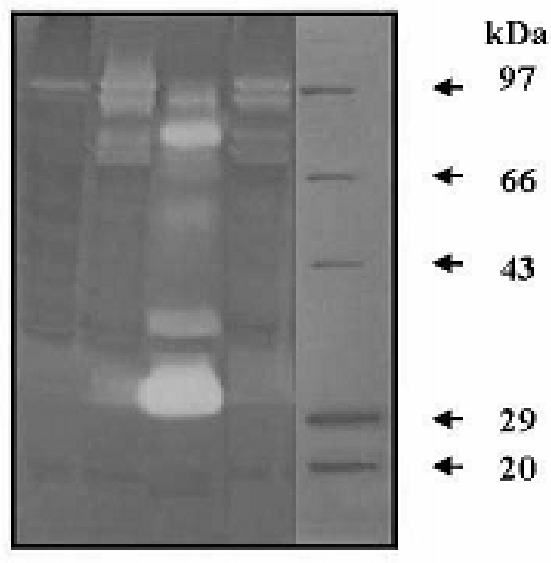

$\begin{array}{lllll}1 & 2 & 3 & 4 & \mathrm{M}\end{array}$

Fig: $5 a$

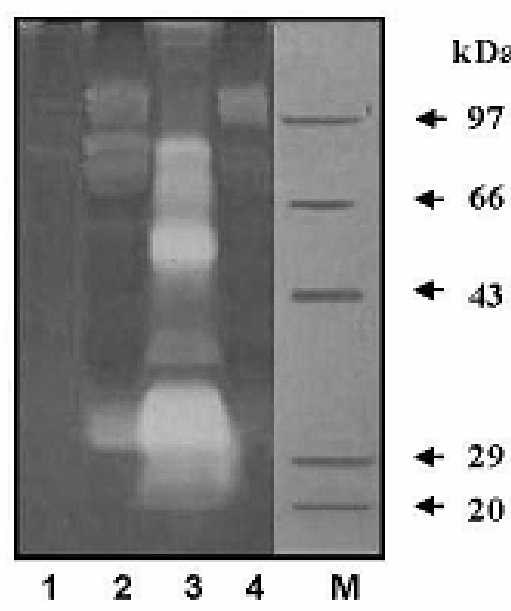

Fig: $5 b$

Figure 5a-5b: Gelatin zymogram of liver samples showing the expression of MMP in experimental mice sacrificed at day 90 (5a) and day 120 (5b). Lane 1=normal diet fed mice; Lane 2=p-DAB+PB fed mice; Lane $3=\mathrm{p}-\mathrm{DAB}+\mathrm{PB}+$ Ethanol fed mice; Lane $4=\mathrm{p}-\mathrm{DAB}+\mathrm{PB}+$ Lycopodium clavatum fed mice.

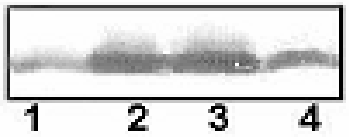

Fig: 6a

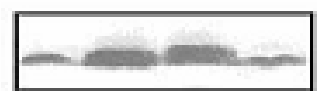

$\begin{array}{llll}1 & 2 & 3 & 4\end{array}$ Fig: $6 \mathrm{~b}$

Figure 6a-6b: Immuno detection of p53 protein expression in experimental mice by western blotting sacrificed at day 90 (6a) and day 120 (6b). Lane $1=$ normal diet fed mice; Lane 2=p-DAB+PB; Lane $3=$ p-DAB+PB+Ethanol fed mice; Lane 4= p-DAB+PB+Lycopodium clavatum fed mice.

The decreased levels of cytotoxicity could also be reflected in the reduced manifestation of tumor nodules in the $\mathrm{p}$ $\mathrm{DAB}+\mathrm{PB}+$ Lycopodium clavatum fed mice. Catalase is an antioxidant enzyme that quenches reactive oxygen species and protects from oxidative damage and reduced glutathione is involved in a number of reactions where it reduces several cellular components. Therefore the catalase and GSH depletion as a result of exposure to carcinogens and the positive alteration (increase) in endogenous GSH contents and catalase activity as a result of administration of the Lycopodium clavatum observed in the present investigation is perfectly in conformity with the modulatory trend in enzymatic activities observed for other enzymes studied in our previous study as well (Pathak et al., 2009). AST and ALT have been linked to hepatocellular injury (Hsu et al., 2009; Yapar et al., 2010). Determination of ALT activity is relatively a sensitive indicator of hepatic damage and release of ALT from the cytosol can occur, secondary to cellular necrosis or as a result of cellular injury with membrane damage, 'bleb' formation (Stockham and Scott, 2002). 
Therefore, from the study of all these biomarkers, it was quite clear that the carcinogens induced severe cytotoxicity, particularly hepato-toxicity during the hepatocarcinogenesis process.

A corresponding increase in genotoxicity level in the carcinogen fed mice was noted from an elevation of frequencies of $\mathrm{CA}, \mathrm{MN}$ and $\mathrm{MI}$ in the bone marrow cells. There was also an increase in sperm with abnormal head morphology. Chromosomes being the carrier of genetic materials and an architect of control for all important functions including metabolic activities, any visible change in chromosome structure (CA, MN) will indicate a possibility of disruption of orderly functioning of metabolic activities, through alteration of DNA structural arrangements that are fine-tuned to regulate expression of genes. There is a positive relationship between some cytogenetical damage and the generation of carcinogeninduced tumors. The increase of $\mathrm{MI}$ in the $\mathrm{p}$ $\mathrm{DAB}+\mathrm{PB}$ fed mice along with the lapse of time depicts signal of increased proliferation and the decrease of $\mathrm{MI}$ in the p$\mathrm{DAB}+\mathrm{PB}+$ Lycopodium clavatum fed mice is an indicator of how the remedy was in action to prevent the act of proliferation. Induction of abnormal sperm head is an indication of the effect of carcinogens affecting the germ cells as well. Therefore, reduction in cytogenetical damage in the $\mathrm{p}-\mathrm{DAB}+\mathrm{PB}+$ Lycopodium clavatum fed mice can be considered as providing important clues for restoration of genetic stability that can act towards intervention of tumorigenesis by regulating and reversing the toxicity process. Similarly, a positive regulation of cyto-toxicity may also contribute towards recovery of cytogenetical damages caused by the carcinogens.

Results of the present study also revealed high level of expression of MMPs, which is generally implicated to tumorigenic and metastastic activities, in $\mathrm{p}-\mathrm{DAB}+\mathrm{PB}$ and $\mathrm{p}-\mathrm{DAB}+\mathrm{PB}+$ Ethanol fed mice showing liver tumors. The expression of MMPs or rather the lack of expression in the p$\mathrm{DAB}+\mathrm{PB}+$ Lycopodium clavatum fed mice would also provide adequate evidence in favor of anti-tumorigenic effects of the homeopathic drug.

p53 is a transcription factor present at minute level in any normal cells, it regulates genes contributing to cell cycle, DNA repair and apoptosis. In the present study, in contrast to the expression level in normal mice, over expression of $\mathrm{p} 53$ proteins has been observed in $\mathrm{p}-\mathrm{DAB}+\mathrm{PB}$ fed and $\mathrm{p}-\mathrm{DAB}+\mathrm{PB}+\mathrm{Ethanol}$ fed mice, quite in tune with the tumorigenic process induced by the carcinogens. In the $\mathrm{p}$ $\mathrm{DAB}+\mathrm{PB}+$ Lycopodium clavatum fed series expression of p53 protein was much less pronounced.

Administration of the spore extract of Lycopodium clavatum could bring about positive modulations of cytotoxicity and genotoxicity induced by the carcinogens and also provided evidences for its anti-cancer potentials by reducing damage, both structural and functional and bringing down tumor number and size. Thus, the results of the present study would add up significant data to indicate that the spore extract possibly acted by suitable modulations of these biochemical and cytogenetical changes; however, the exact mechanisms involved could not be fully understood at the present state of our knowledge. Although the exact ingredient(s) which is (are) most bioactive can not be stated from the results of this study, it can be fairly generalized that the spore extract as a whole had an overall ameliorative effect against hepatotoxicity and anti-oxidative stress produced by the carcinogens. Therefore, further in-depth studies to identify the active principles of the extract which have the most dominant anti-cancer effect need to be made to pinpoint the modus operandi of this drug. This can form the basis for future studies. Although people are now more prone to using complementary and alternative medicines (CAM), particularly in the management of carcinogenesis, many are averse to it because of lack of experimental validation and lack of understanding of the precise mechanism of action. Therefore, such controlled animal experimentations should be performed by 
researchers independently for this and other alternative medicines that are found to have clinical benefits by many practitioners of CAM, but actually lack experimental validation. Results of the present work would show that the Lycopodium clavatum has ameliorative potentials against hepatotoxicity as well as genotoxicity and also it has considerable anti-cytotoxic effect. Therefore, the use ethanolic spore extract of Lycopodium clavatum in form of traditional medicine as a candidate for hepato-protective and antigenotoxic agent can be seriously considered.

\section{ACKNOWLEDGEMENTS}

The authors are grateful to the Department of AYUSH, Govt. of India, New Delhi for granting an EMR project to Prof. A.R. Khuda-Bukhsh, Dept of Zoology, University of Kalyani, Kalyani, Nadia, West Bengal, India.

\section{REFERENCES}

Bergmeyer HU, Brent E. 1974. Methods of Enzymatic Analysis. Academic Press: New York.

Billings PC, Habres JM, Liao DC, Tuttle SW. 1991. Human fibroblasts contain a proteolytic activity, which is inhibited by the Bowman - Birk protease inhibitor. Cancer Res., 51: 5539-5543.

Biswas SJ, Khuda-Bukhsh AR. 2005. Cytotoxic and genotoxic effects of the azo-dye $p$-dimethylaminoazobenzene in mice: A time-course study. Mutat. Res., 587: $1-8$.

Biswas SJ, Pathak S, Khuda-Bukhsh AR. 2004. Assessment of the genotoxic and cytotoxic potential of an anti-epileptic drug, phenobarbital, in mice: a time course study. Mutat. Res., 563: 1-11.

Biswas SJ, Bhattacharjee N, Khuda-Bukhsh AR. 2008. Efficacy of a plant extract (Chelidonium majus L.) in combating induced hepatocarcinogenesis in mice. Food. Chem. Toxicol., 46(5): 1474-1487.

Buege JA, Aust SD. 1984. Microsomal lipid peroxidation. Methods. Enzymol., 105: 302-310.
Chance B, Maehly AC. 1955. Assay of catalase and peroxidase. Methods. Enzymol., 2: 764-775.

Daoust R. 1962. The mitotic activity in rat liver during DAB carcinogenesis. Cancer. Res., 22: 743-747.

Ellman GL. 1959. Tissue sulfhydryl groups. Arch. Biochem. Biophys., 82: 70-77.

Hsu YW, Tsai CF, Chen WK, Lu FJ. 2009. Protective effects of seabuckthorn (Hippophae rhamnoides L.) seed oil against carbon tetrachloride-induced hepatotoxicity in mice. Food. Chem. Toxicol., 47(9): 2281-2288.

Kitagawa T, Sugano H. 1977. Enhancement of azodye hepatocarcinogenesis with dietary phenobarbital in rats. Gann., 68: 255-256.

Kitagawa T, Pitot HC, Miller EC, Miller JA. 1979. Promotion by dietary phenobarbital of hepatocarcinogenesis by 2-methyl-N, $\mathrm{N}$-dimethyl-4-aminoazobenzene in the rat. Cancer. Res., 39(1): 112-115.

Lowry OH, Rosebrough NJ, Farr AL, Randall RJ. 1951. Protein measurement with Folin-Phenol reagent. J. Biol. Chem., 193: 265-275.

Ma X, Gang DR. 2004. Lycopodium alkaloids. Nat. Prod. Rep., 21: 752.

Magi B, Bini L, Marzocch B, Liberatori S, Raggiaschi R, Pallini, V. 1999. Immunoaffinity identification of 2-DE separated proteins. In 2-D Proteome Analysis Protocols:Methods in Molecular Biology. Humana Press: New Jersey; 313318.

Mandal SK, Biswas R, Bhattacharyya SS, Paul S, Dutta S, Pathak S, Khuda-Bukhsh AR. 2010. Lycopodine from Lycopodium clavatum extract inhibits proliferation of HeLa cells through induction of apoptosis via caspase-3 activation. Eur. J. Pharmacol., 626(2-3): 115-22.

Palekar SD, Sirsat SM. 1966. Studies on hepatocyte in azo dye carcinogenesis. Indian. J. Exp .Biol., 4: 73-78.

Pathak S, Khuda-Bukhsh AR. 2006. Assessment of hepatocellular damage and hematological alterations in mice chronically fed p-dimethylaminoazo- 
benzene and phenobarbital. Exp. Mol. Pathol., 83: 104-111.

Pathak S, Bhattacharjee N, Das JK, Choudhury SC, Karmakar SR, Banerjee P, Paul S, Banerjee A, Khuda-Bukhsh AR. 2007. Supportive evidences for anticancerous potential of an alternative medicine in hepatocarcinogenesis of mice. Forsch. Komplementarmed., 14: 148-156.

Pathak S, Banerjee A, Paul S, Khuda-Bukhsh AR. 2009. Protective potentials of a plant extract (Lycopodium clavatum) on mice chronically fed hepato-carcinogens. Indian. J. Exp. Biol., 47: 602-607.

Rusu MA, Tamas M, Puica C, Roman I, Sabadas M. 2005. The hepatoprotective action of ten herbal extracts in $\mathrm{CCl} 4$ intoxicated liver. Phytother. Res., 19(9): 744-749.

Schmid W. 1976. Principles and Methods of Detection. In Chemical Mutagens, Hollaender AE (ed). Plenum Press: New York; 55.

Stockham SL, Scott MA. 2002. Fundamentals of Veterinary Clinical Pathology. Iowa State University Press: Ames; 434-459.

Wyrobek AJ, Watchmaker G, Gordon L. 1984. Handbook of mutagenecity testing protocols. Elsevier Science: Netherland.

Yapar K, Cavuşoğlu K, Oruç E, Yalçin E. 2010. Protective role of Ginkgo biloba against hepatotoxicity and nephrotoxicity in uranium-treated mice. J. Med. Food., 13(1): 179-88. 